\title{
A ANTROPOLOGIA HISTORICIZADA OU OS ÍNDIOS DE FENIMORE COOPER: CLÁSSICOS E HISTÓRIA NO ENSINO DE ANTROPOLOGIA NO BRASIL*
}

\author{
Guillermo Vega Sanabria
}

\begin{abstract}
[...] la Révolution française tel qu'on en parle n'a pas existé.
(Claude Lévi-Strauss, La pensée sauvage).
\end{abstract}

\begin{abstract}
Se me disserem que é absurdo falar assim de quem nunca existiu, respondo que também não tenho provas de que Lisboa tenha alguma vez existido, ou eu que escrevo, ou qualquer cousa onde quer que seja

(José Saramago, O ano da morte de Ricardo Reis).
\end{abstract}

Com seu desenvolvimento "totalmente vinculado a instituições públicas, basicamente às universidades" (Ribeiro \& Lima 2004:10), os programas de pós-graduação têm se tornado referência obrigatória para se conhecer a antropologia ensinada no Brasil e locus por excelência da reprodução disciplinar (Corrêa 1995). Nas permanentes reflexões sobre o ensino de antropologia no país (cf. Godoi \& Eckert 2006; Grossi et al. 2006; Tavares et al. 2010; Trajano Filho \& Ribeiro 2004), destaca-se o apelo explícito para usar o saber antropológico para "entender melhor o que nós [antropólogos] fazemos" (Correa 2006:106); para efetuar "uma etnografia detalhada e detalhista na universidade", uma análise do sistema cultural do qual faz parte o ensino (Fry 2006:66-67). Conforme Correa, "precisamos saber mais sobre como se dá o processo de transmissão de nossa disciplina, nos cursos de graduação e pós-graduação" (2006:109). Esta autora também sugere a possibilidade de um "roteiro para pensarmos sobre como, no quadro dos programas de pós-graduação - a nova tribo de referência dos antropólogos se deram as relações entre as gerações, como se definiram as posições sociais e como a cultura antropológica foi transmitida" (Correa 1995:73). No mesmo sentido, Cardoso de Oliveira perguntava: 
[Se] nós mesmos, enquanto antropólogos, membros de uma comunidade intelectual, constituímos uma sorte de "cultura", cujas origens não estão aqui, em nosso continente, mas em nossa formação profissional estão presentes, por que então não tomamos essa "cultura" como objeto privilegiado de nossas indagações? (1997:15; grifos do autor).

Porém, apesar destes apelos explícitos, a lista de pesquisas empíricas sobre o tema resulta ainda curta. Na literatura sobre a configuração da antropologia no país - incluindo a questão do ensino - predominam as memórias e os textos ensaísticos, sustentados em opiniões e vivências pessoais. Precisamente o fato de esses textos privilegiarem reminiscências e quase sempre resultarem do compromisso militante dos autores impede tomá-los como única base do estudo do campo antropológico. Tal como alertaram Latour e Woolgar ao fazerem um balanço da literatura sobre a ciência e as práticas científicas, é necessário reconhecer que "por mais estimulantes que sejam essas obras, elas não podem remediar a ausência de pesquisa, de observação direta, de contradição" (1997:19).

A partir de uma pesquisa em seis Programas de Pós-Graduação em Antropologia (PPGA), este artigo explora o vínculo entre a formalização do ensino através das grades curriculares, a seleção de conteúdos nas disciplinas obrigatórias e a compreensão dos clássicos e o seu lugar no ensino da perspectiva dos professores. ${ }^{1} \mathrm{O}$ trabalho enfoca o papel atribuído às obras e aos autores tidos como "clássicos" e as distinções que, no contexto do ensino, os professores entrevistados estabelecem entre "história" e "teoria" antropológica. Parte-se da ideia de que as características das grades curriculares e o fato de certos autores, textos e temas serem privilegiados nas disciplinas obrigatórias - enquanto outros são excluídos ou postergados - exprimem uma hierarquização do conhecimento antropológico destinado ao ensino neste nível. Essa hierarquização, por sua vez, remete a um cânone para a formação dos novos antropólogos no Brasil, mas também a traços idiossincráticos das relações sociais nos cursos de antropologia. Com base na análise qualitativa de grades curriculares e programas de disciplinas obrigatórias de seis PPGAs, assim como na revisão de arquivos e entrevistas com 25 professores em quatro dos seis PPGAs iniciais, temas como as relações interinstitucionais e intergeracionais, a divisão do trabalho e a reprodução social surgem como questões centrais neste contexto. ${ }^{2}$

\section{Por falar em "clássicos"}

Durante minha incursão nos PPGAs deparei-me com a insistência de alguns interlocutores sobre a necessidade de que meu trabalho contemplasse as 
diferenças existentes entre esses programas, especialmente em termos regionais. Se no início a relevância desta questão não era completamente evidente para mim, ao longo do trabalho de campo constatei que, com efeito, em cada local existia um claro interesse em afirmar suas diferenças em relação aos outros PPGAs. Adverti então que a criação de histórias das antropologias locais adquiria um papel central no ensino da disciplina, haja vista, como asseverava um entrevistado, suas "inúmeras particularidades". Este fato reforçou minha escolha dos PPGAs do Museu Nacional, UFPE, UFRGS e USP para o levantamento de informações in situ, na medida em que afirmar tais diferenças constituía um autêntico leitmotiv a partir do qual enunciavam-se as que eram consideradas marcas institucionais dos cursos.

Ao refletir sobre o ensino e, em particular, sobre a introdução dos novos alunos ao conhecimento antropológico, os professores nesses locais também enfatizavam o papel dos "clássicos". Assim, nas primeiras tentativas de caracterizar as disciplinas obrigatórias nos PPGAs, defrontei-me com o problema de definir operacionalmente o que era uma obra ou um autor "clássico". Em contraste, o significado deste termo parecia surgir inequivocamente para os professores entrevistados e, ora referido a autores, ora a obras, ora a temas, era sintetizado numa expressão por eles usada recorrentemente: "não dá para falar de antropologia sem falar de...".

Na prática, qualquer definição de "clássico" pode comportar várias acepções. Numa linguagem científica e técnica, o termo clássico designa noções, objetos e experiências tidas como primordiais, no sentido cronológico. Também remete a soluções reconhecidas socialmente como fundamentais e exemplares por uma comunidade de especialistas ou pelo grande público e, amiúde, conhecidas e usadas extensamente. O termo pode ser empregado em função de contextos variáveis, de maneira que um autor ou uma obra podem ser considerados clássicos nos limites de um território, de uma época, de um campo de conhecimento ou de uma tradição intelectual. São critérios de tipo cronológico e de consagração, por exemplo, os expressados por Evans-Pritchard ao se referir a The Argonauts of the Western Pacific (de Malinowski) como uma obra clássica por ser "o primeiro trabalho em seu gênero" e por seu "considerável mérito" (1964: 93; grifos meus).

A tentativa de definir o que seja clássico pode assumir tanto a perspectiva das propriedades de uma obra ou de um autor como a perspectiva dos sistemas normativos do grupo social que lhes confere esse estatuto. No primeiro caso, enfocam-se os aspectos formais do objeto e sua função referencial ou técnica. Estes critérios fizeram carreira na visão moderna da estética e da literatura denotando temáticas e um conjunto de processos estilísticos. No segundo caso, aponta-se de maneira privilegiada para a dimensão ética 
que subjaz à noção de clássico. Esta dimensão pode ser constatada, sobretudo, nas controvérsias seculares entre representantes da cultura antiga e da cultura moderna (tipicamente entre "clássicos" e "românticos") e na contraposição das vanguardas históricas, contexto no qual o ideal de clássico opera como metáfora de opções éticas e políticas (Fortini 1989). É neste sentido, aliás, que opera a noção de clássico na oposição que vários entrevistados nos PPGAs estabeleciam em relação aos autores "pós-modernos".

A adoção de qualquer critério a partir do qual possa ser definido o termo "clássico" dificilmente esgota todas as suas possíveis acepções ou garante a total consistência de sua definição. No entanto, o que me interessa destacar no raciocínio dos professores entrevistados é que a noção de clássico já emerge como um primeiro divisor dos conhecimentos antropológicos no ensino. Ela estabelece uma hierarquia entre obras e entre autores pela sua antiguidade (critério cronológico, a partir do qual o termo pode ser oposto a "contemporâneo"); seu reconhecimento ou sua consagração num determinado âmbito (critério contextual); e seu uso (critério estatístico). É bem verdade que existe uma virtual diferença entre, por um lado, o que é proposto formalmente no ensino - tal como materializado nas grades curriculares e nos programas das disciplinas - e, por outro lado, o que é efetivamente ensinado numa sala de aula ou na formação do antropólogo alhures - notadamente através do trabalho de campo e da orientação (cf. Peirano 2006a). Contudo, essa diferença, que seria análoga à que existe em outros contextos entre o que é escrito ou dito e o que é feito, não desmerece esta análise. Proponho que a forma de classificar obras e autores e, em geral, o conhecimento antropológico no ensino institui também uma maneira de identificar seus portadores, a partir dos valores que tal hierarquia estabelece. É de seu uso social que, doravante, deriva o interesse na noção de clássico porque, muito além das definições que porventura possam ser adotadas, é precisamente por meio de seu uso social que se evidencia sua maior consistência.

\section{O sorriso dos mortos}

Nas discussões e nos textos nos quais o assunto é proposto explicitamente, é frequente achar expressões que denotam o papel simbólico que os clássicos cumprem na configuração da comunidade profissional dos antropólogos e em sua orientação intelectual. Assim, autores considerados clássicos são chamados também de "fundadores" (Laraia 2008), "pais fundadores" (Bomeny \& Birman 1991:12; Brandão 1997:10-11; Duarte 2006:20, 27; Fonseca 2006a:154; 2006b:219; Motta, A. \& Brandão 2004:167; Peirano 2006b:90; Trajano Filho 
2006:289), "heróis" (Woortmann 2006:185), "heróis fundadores" (Hutzler 1997:50; Laraia 1991:59; Peirano 1995:16; Ribeiro R. \& Hutzler 1991:70; Santos 1997:62), "heróis civilizadores" (Cardoso de Oliveira 1997:112), "fundadores de linhagens" (Brandão 1997:12; Peirano 1995:21), "xamãs" (Fonseca 2006a), "mestres" (Sanchis 2006:120), "ancestrais" (Fonseca 2006a:154; Peirano 1995:21, 37; 2006:82; Viveiros de Castro 1995:6) e "mentores intelectuais" (Peirano 1995:148). Consequentemente, a importância atribuída à sua necessária inclusão no ensino pode expressar-se do seguinte modo:

É através da viagem em companhia de nossos pais fundadores, da convivência com eles e com nossos contemporâneos — nas ilhas Trobiand e em outros lugares exóticos, que nossos alunos adquirem uma linguagem comum e, por conseguinte, uma determinada identidade. Sugere-se que essa herança se assemelha a um grupo de descendência, uma linhagem que une seus membros em um tipo de grupo corporado (Fonseca 2006a:154; grifos meus).

Segundo Peirano, "os antropólogos tendem a reconhecer que partilham ancestrais e linhagens comuns, por intermédio dos quais iniciam os estudantes em qualquer parte do mundo". O que esta autora nomeia de "história-teórica" da antropologia estaria referido então a "um elenco de autores e monografias [que] se transforma, em determinado contexto, numa linhagem socialmente consagrada da disciplina" (2006b:82, 89; grifos meus em ambas as citações). É precisamente nesse contexto que se destacam os apelos para enfatizar a história ("teórica") no ensino da antropologia e privilegiar os temas, os textos e os autores considerados clássicos (cf. Correa 2006; Duarte 2006; Fonseca 2006a; Peirano 1991, 1995, 1997, 1999, 2004, 2006b; Sanchis 2006; Viveiros de Castro 1995; Woortmann 2006). Lançar mão dos clássicos no ensino constituiria, como indica uma entrevistada, uma "tática pedagógica", mas também é "simplesmente uma profissão de fé, [do] que reconhecemos como parte de uma tradição que nós prezamos". É a partir dessa dupla função didática e sociológica aqui aventada que se poderia entender o estreito vínculo sugerido pelas colocações acima entre a ideia de clássico e a de ensino. Ou, em outras palavras, o duplo uso da noção de clássico em sua acepção referencial (técnica) e em sua acepção normativa (ética), proposto acima. Daí que termos como "base", "fundamento", "tradição" e ainda "verdadeiro" sejam utilizados como sinônimos pelos professores entrevistados e possam ser intercambiados com flexibilidade no discurso sobre o ensino dos clássicos.

Uma vez que obras e autores considerados clássicos permitem introduzir os novos alunos no conhecimento geral da antropologia, eles estão no 
início e têm um caráter obrigatório, ocupando uma posição privilegiada no processo de formação dos futuros antropólogos. E sendo que, de acordo com as caracterizações feitas por uma entrevistada, "os alunos chegam quase semiágrafos, praticamente ágrafos", disciplinas de cunho histórico e teórico enfocando autores e obras clássicas e distintas das disciplinas "de ponta" estão presentes para "alfabetizar" ou para "suprir as deficiências de conhecimento teórico" e "situar o aluno para se apropriar de um legado". Haja vista que "não adianta pegar um manual sem ver o que foi feito antes", a leitura dos autores e dos textos clássicos é assinalada como a melhor maneira para aprender, porquanto eles portam "a grande teoria antropológica" e porque "clássico é uma etnografia, com trabalho de campo". Os textos clássicos serviriam de "corrimão para o aluno, para o pesquisador, o iniciante", não como "um conjunto de receitas, [mas como] uma monografia de referência", como coloca outro entrevistado. Eles ofereceriam um modelo de escrita inclusive em termos estilísticos e retóricos, mas, sobretudo, em termos de raciocínio.

Esta é, decerto, uma compreensão generalizada nas reflexões sobre o ensino de antropologia no Brasil e uma peça central do discurso em torno da produção da identidade profissional de muitos antropólogos neste contexto. Essa maneira de entender os clássicos e de invocá-los, por um lado, estabelece de início uma hierarquia entre os objetos do ensino, à medida que revela a preocupação de distingui-los do conjunto geral de obras e de autores precisamente porque considerados dignos de serem conservados pela transmissão escolar (Bourdieu 2003:215). Por outro lado, diz respeito às relações que os encarregados do ensino estabelecem com esses objetos e o papel que eles viriam a cumprir na reprodução disciplinar. Aqui como em outros contextos, mutatis mutandi, o fato de que o completo conhecimento da história social esteja reservado a certos membros do grupo - geralmente os mais velhos - e que em qualquer caso eles devam ser autorizados para desempenhar essa função especializada, sem dúvida estabelece uma assimetria estruturante das relações e uma regra geral na transmissão social do conhecimento. O estabelecimento destas élites déjà intellectuelles (Mauss 1969:337) encarregadas de preservar e transmitir a tradição revela, pois, um princípio de organização social em torno do conhecimento passível de ser passado de geração em geração.

\section{A piedade filial}

É precisamente esse princípio de organização social que parece emergir nas classificações a partir das quais os professores entrevistados se distinguem 
de outros grupos, atribuem valores diferenciados à sua própria formação e buscam se associar ou se afastar de certas tradições intelectuais, consideradas mais ou menos "clássicas". Por isso, embora se reconheça a importância de propiciar no ensino um sentido crítico em relação aos clássicos (Cf. Correa 1997; Fonseca 2006a; Peirano 1997; Viveiros de Castro 1995; Woortmann 2006), as colocações a respeito surgem para corroborar a necessidade de sua plena incorporação. Nesta direção, um entrevistado afirma: "eu não estou com isso dizendo que esses autores detêm a verdade. Só estou dizendo que é o nosso mito [e] precisamos nos inserir no mito".

Os depoimentos dos entrevistados acerca de sua própria experiência como aprendizes de antropologia permitem apontar dois fatos: 1 . As referências às mudanças nas condições de formação pós-graduada no Brasil. Um entrevistado descreve tais mudanças como uma "toyotização da formação" para falar do incremento do número de alunos, a redução de prazos e a titulação em série; 2 . O fato de que constatar as diferenças entre a formação das gerações anteriores e a das novas permite aos entrevistados efetuar duas classificações. Ambas remetem à assimetria estruturante das relações mencionada acima ou, mais precisamente, introduziriam os primeiros elementos de uma "distância estrutural" a partir da qual se organizam as interações no contexto do ensino, isto é, "a distância entre grupos de pessoas dentro de um sistema social, expressa em termos de valores" (Evans-Pritchard 1978:23).

A primeira dessas classificações consiste em distinguir como clássica a própria formação, independentemente do local e da época em que ela aconteceu, em contraste com outras formações que, deste ponto de vista, seriam menos clássicas. Um aspecto enfatizado aqui são as condições nas quais a própria formação teria se desenvolvido, especialmente a respeito da pesquisa etnográfica. A noção de "clássico" surge então para enfatizar diferenças entre o modelo de pesquisa das velhas gerações (os atuais professores) e o modelo das novas (os atuais alunos). A expressão "trabalho de campo clássico" - um dos traços distintivos de uma formação "clássica", segundo os entrevistados designaria a pesquisa in locus, realizada durante um período mais longo do possível hoje em dia. Mas, também, trabalho de campo clássico seria aquele que se ajusta a um modelo de pesquisa emblemático: a la Malinowski. Ao redor desta ideia criam-se distinções para os indivíduos que tiveram esse tipo de experiência e, principalmente, para instituições em que isto teria sido possível. Por exemplo, ao descrever o modelo de pesquisa no qual ele afirma ter se formado, um entrevistado vê nesse modelo a "revelação" do "gen malinowskiano" que seria característico do local onde ele se formou. Ao mesmo tempo, ele justifica a histórica exclusão de disciplinas obrigatórias de cunho metodológico da grade curricular de seu curso indicando: 
A ideia é que [uma disciplina de] metodologia é para quem não vai para o campo e que toda a metodologia é observação participante, ir para o mato, aprender a língua. Para o mato ou, enfim, o que faça às vezes de mato. O que fazia as vezes de metodologia era a leitura das etnografias anteriores. Você ia para o campo porque [o que] tinha como referência era a literatura produzida sobre o teu campo e, eventualmente, digamos assim, as monografias que você tinha colocado como modelo do teu trabalho.

A comparação entre as antigas e as atuais condições de formação surge do pressuposto de que existe uma forma canônica de pesquisa antropológica ou, nas palavras de uma entrevistada, de uma "etnografia ideal", que seria "o convívio mais aprofundado, a presença no local". Ao referir-se às condições atuais do trabalho de campo e criticar as restrições impostas pelas agências financiadoras, os entrevistados reforçam a distinção entre as velhas e as novas gerações de antropólogos, uma vez que, como expressa sinteticamente a mesma entrevistada, “agora não se tem mais isso. Então os alunos têm que fazer disciplinas e já têm, de certa forma, que coletar dados. Como não têm muitas condições de fazer observação [prolongada], acabam fazendo [apenas] algumas observações e [ficam] muito centrados em entrevistas".

A segunda classificação feita pelos professores entrevistados é em relação às instituições onde eles se formaram. Embora a maioria apontasse diferenças locais quanto a modelos curriculares e culturas institucionais, eles destacam as semelhanças que os cursos brasileiros tiveram desde o início com seus homólogos em outros países. Se comparados com os cursos no estrangeiro - nos quais mais da metade dos entrevistados se formou e referidos como centros "tradicionais" da antropologia — os primeiros cursos nacionais não teriam deixado nada a desejar. Alguns entrevistados assinalaram que a formação em antropologia no Brasil "não era tão diferente" da formação no exterior e, ao contrário, existia uma "familiaridade", uma "linguagem" comum. Para esses entrevistados, a semelhança podia ser atribuída ao fato de alguns acadêmicos estrangeiros, procedentes dos "centros metropolitanos da antropologia", terem participado na criação dos primeiros cursos de pós-graduação no país, mas também ao "caráter internacional" com que esses cursos foram concebidos desde o início. O interessante aqui é que, independentemente dos traços comuns ou das diferenças que por ventura existissem, as semelhanças com os centros de formação "metropolitana", "tradicional", são enfatizadas, enquanto as diferenças são pouco explanadas. ${ }^{3}$

Porém, ao mesmo tempo em que serve para aproximar cursos nacionais e estrangeiros, invocar a tradição serve também para enunciar distinções entre os PPGAs nacionais. E, inclusive, para salientar diferenças entre as 
primeiras e as mais recentes gerações de professores dentro de um mesmo PPGA. Os entrevistados que se referiam à história da institucionalização da antropologia no Brasil identificavam o predomínio inicial da chamada "antropologia cultural", "boasiana" ou "americana", associada em todos os locais onde foram entrevistados professores às gerações mais velhas nos "primórdios" dos cursos (cf. também Corrêa 1995; Hutzler 1997; Motta R. 1997; Rubim 1996). O deslocamento dessa antropologia para uma "antropologia social" de cunho "franco-britânico" justificaria, de acordo com um entrevistado, a mudança da expressão "antropologia cultural", adotada anteriormente no nome de um curso. Segundo esse entrevistado, "talvez os [professores] velhos sejam mais culturais". Todavia, a mudança do antigo nome não conduziu à adoção da expressão mais frequente "antropologia social" na nova denominação. Isto porque, segundo o entrevistado, um dos traços distintivos do seu programa é a "diversidade de formações" de seus professores. Referia-se assim ao fato concreto de os professores desse programa terem se doutorado em locais associados a diversas tradições intelectuais, no estrangeiro e no Brasil. Para ele, diante dessa diversidade, não poderia se afirmar a existência de uma "linha única", isto é, de uma "corrente" de pensamento característica do curso em que atua.

Em suma, o que interessa destacar nestas classificações alicerçadas na noção de clássico é, por um lado, seu papel de grande divisor entre velhas e novas gerações e, por outro, como forma de distinção institucional dos PPGAs. Quando invocada pelos entrevistados para caracterizar sua formação, a noção de clássico diz respeito às qualidades de uma experiência que pareceria cada vez mais longínqua e os diferenciaria das gerações atuais. Referindo-se à origem e à consolidação dos cursos, cada um reivindica a pertença a uma "tradição", aproximando os cursos nacionais dos centros acadêmicos de antropologia na Europa e nos Estados Unidos. Mas, ao mesmo tempo, cada um afirma a especificidade de seu curso no contexto nacional, considerando-o possuidor de um estilo de formação que se ajustaria aos padrões ditos clássicos.

Considerando as relações sociais nas quais se invoca "o clássico", tal noção remete ao passado e orienta os esforços de quem a invoca para conservar os valores dos quais esta noção seria portadora. Daí que mesmo sendo possível introduzir eventuais mudanças nas disciplinas que objetivam o ensino dos "clássicos", como reconhece um entrevistado, "a possibilidade de inovar não é absoluta". Em todo caso, é preciso "seguir, digamos assim, a voz corrente, quase o senso comum da disciplina". Reforçadas as escolhas individuais (dos professores) pelo "senso comum da disciplina", enfatizam-se então no ensino as cronologias e as filiações com os antigos, seleciona-se e remete-se constantemente ao cânone dos autores, das obras, do método e 
das tradições intelectuais que ao longo do tempo seriam dignos de favor e de serem conservados porque considerados como excelentes. Isto, decerto, é funcional do ponto de vista do ensino e da socialização mais ampla. Em primeiro lugar, porque orienta a seleção e a organização dos conteúdos passíveis de serem transmitidos. Em segundo lugar, porque estabelece a preeminência dos mais velhos sobre os mais novos, mas também garante a reprodução do sistema, uma vez que os mais novos, identificando-se com os mais velhos, buscam se inserir nessa tradição e participar de seus valores.

\section{Olhando através das grades}

A formação pós-graduada em antropologia no Brasil concretiza-se nas grades curriculares dos cursos em duas grandes classes de disciplinas: 1. as obrigatórias e 2. as "eletivas", "optativas" ou "opcionais". Por seu caráter compulsório, as disciplinas obrigatórias são comuns a todos os estudantes (mestrandos e doutorandos). Em geral, elas visam prover os alunos com uma linguagem conceitual básica e introduzi-los no conhecimento antropológico geral. O grupo das "eletivas", "optativas" ou "opcionais" objetiva a formação em áreas especializadas e possibilita a inserção dos alunos em subcampos e temas específicos. Considerando seus propósitos globais, explícitos nos regimentos dos PPGAs e nas ementas das disciplinas, é possível identificar, por sua vez, dois grandes grupos de disciplinas obrigatórias: um apontando para uma formação conceitual e outro, para uma formação metodológica. No grupo das disciplinas conceituais podem distinguir-se ainda disciplinas de cunho explicitamente "histórico" e outras de cunho explicitamente "teórico". Como nem todos os PPGAs incluem disciplinas de cunho metodológico na grade curricular obrigatória, as disciplinas de cunho histórico e teórico constituem o mínimo comum do ensino nos seis PPGAs pesquisados.

A relação entre história, teoria e método tem sido objeto de reflexões, notadamente a partir do que Peirano (1995, 1997, 2004, 2006b) denomina de "história teórica" da antropologia. A este respeito a autora aponta:

Escolho a expressão história-teórica para designar um elenco de autores e monografias [que] se transforma, em determinado contexto, em uma linhagem socialmente consagrada da disciplina. Isto é, a história teórica pode assumir formas variadas, mas sua presença constante é elemento essencial da cosmovisão dos antropólogos. Empiricamente, ela se traduz como uma reinvenção disciplinar, resultado do encontro entre teoria acumulada e dados etnográficos novos que são vistos, pelos antropólogos-praticantes, como a história teoricamente significativa. 
A centralidade da história teórica pode ser observada em várias circunstâncias da vida acadêmica: na bibliografia citada pelo autor de um artigo, nas referências implícitas a uma determinada conferência, nos mentores intelectuais de um antropólogo em particular. Como criação cultural, a história teórica da disciplina seleciona, ou "pinça", um certo tema, abordagem ou autor como significativos em determinado momento. Trata-se de um fenômeno que, tal como na visão clássica de Marcel Mauss a respeito da magia, legitima uma dada vertente dentro do panteão de antecessores disciplinares (1995:36; grifos da autora).

Os professores entrevistados nos PPGAs pareciam compartilhar uma visão similar, reconhecendo a existência de uma relação basilar e indissociável entre história, teoria e método. Conforme seus depoimentos, esta relação basilar e indissociável estaria na origem das escolhas tanto da construção das grades curriculares dos cursos quanto dos programas das disciplinas por eles ministradas. Contudo, ao menos do ponto de vista de sua organização formal nas grades e nos programas, tais noções surgem menos integradas e, ao contrário, claramente diferenciadas para efeitos do ensino. Isto vale inclusive nos cursos que não contam em suas grades com disciplinas de cunho explicitamente histórico (Museu Nacional, UFRGS) e metodológico (Museu Nacional, UnB) no grupo das obrigatórias. Distinções deste tipo são reforçadas pelas hierarquias que, paulatinamente, os entrevistados estabeleciam entre disciplinas e a partir das quais outorgavam preeminência à "teoria" sobre a "história" e à formação no "método" antes de qualquer "pretensão teorizante". ${ }^{4}$

Para além das circunstâncias institucionais e das motivações didáticas que originaram a grade curricular de cada PPGA, as explanações que os entrevistados ofereciam sobre essas hierarquias entre disciplinas remetem, afinal, a outras classificações, desta vez no âmbito das relações sociais mais amplas dentro e entre os PPGAs. Ao se referir à inclusão de uma disciplina obrigatória metodológica na grade de seu curso, um entrevistado afirma categoricamente que a antropologia não se caracteriza por uma teoria específica, mas por um modo de fazer, isto é, por seu método. Segundo o entrevistado, esta tem sido a marca distintiva da antropologia desde o surgimento da "antropologia britânica", a partir da qual se originou uma "tradição de pesquisa de campo" que se opôs em seu momento, por exemplo, "à abstração marxista". Nesse sentido, a preeminência do método em antropologia decorreria da "necessidade de fazer pesquisa", antes de "teorizar". Embora uma afirmação como esta encontre seu avesso nas críticas de uma entrevistada ao afirmar que uma disciplina não pode ser definida "simplesmente pelo método", é possível que seja a importância atribuída à etnografia que sustente um critério assinalado amiúde pela literatura sobre o ensino de 
antropologia e pelos entrevistados ao tratar da montagem das disciplinas obrigatórias. Tal critério consistiria em privilegiar na bibliografia a inclusão de "etnografias em si", e não só (ou nem tanto) textos de historiadores da antropologia e comentadores.

Em contraste com a ênfase no "método", outra entrevistada distingue disciplinas "pesadamente teóricas" das "práticas", enquanto realça a "tradição teórica muito forte" de sua universidade. Nessa mesma direção, quando interrogado sobre a ausência na grade curricular de uma disciplina obrigatória que aborde explicitamente a "história" da antropologia, um entrevistado vê nisso o "viés teorizante" de seu PPGA. Este "viés teorizante" significa, em suas palavras, não serem "repetidores", mas "produtores de teoria". Mesmo relativizando a seguir essa afirmação, o entrevistado pode asseverar assim que "nós estamos aqui em pé de igualdade com o centro internacional". É em relação às disciplinas "históricas" que esta valorização das disciplinas "teóricas" parece mais reforçada. Nas palavras de uma entrevistada:

Se você fosse [ministrar] história da antropologia, é outro curso [porque] você vai privilegiar uma outra bibliografia. Este não é o objetivo de [nome da disciplina "teórica"]. Quer dizer, se você observar os programas, há uma preocupação de contextualização histórica, mas não em ter a história como objeto. É completamente diferente. Eu não sei como são os outros cursos, mas eu acho que é pertinente que a gente chame de teoria porque de fato é teoria e não é história. Eu dou disciplinas na área de história da antropologia. São disciplinas completamente diferentes. O objetivo não é transformar o aluno num repetidor, mas fornecer a ele instrumentos para compreender a problemática dos diferentes autores que marcaram a disciplina. E também tentar fazê-los compreender porque é que determinados autores se tornaram referência e outros não. Mas aí isso já entra no domínio da história da antropologia...

Outra entrevistada reconhece que, embora duas disciplinas obrigatórias de seu PPGA sejam chamadas de "Teoria Antropológica", nelas interessa também introduzir uma abordagem histórica. Todavia, enfatiza que não se trata "simplesmente de história da antropologia", mas "história das teorias antropológicas" porque "essa parte está junto". Nessa mesma direção, outra entrevistada declara seu interesse na história afirmando que, ao ministrar uma disciplina obrigatória de cunho teórico, buscou "trabalhar a antropologia historicamente, fazer uma história das ideias". Porém, imediatamente esclarece que não se trata "simplesmente [de] resumir as ideias ou organizar elas em temas lógicos ou filosoficamente. [O programa da disciplina] está tentando trabalhar a história da ciência...". Enfim, justificando a inclusão 
da "história" da antropologia nas disciplinas obrigatórias e a denominação de uma disciplina usando a expressão "história", um entrevistado em outro curso indica que "é para insistir que as teorias estão contextualizadas dentre as histórias", uma vez que, a seu ver, não é possível "trabalhar elas [as teorias] a partir de uma visão epistemológica árida, na qual elas têm uma realidade fora dos contextos históricos em que aparecem". Note-se contudo que, caso sejam colocadas "juntas", isto não significa necessariamente que seja atribuído o mesmo estatuto à "história" e à "teoria". Muito pelo contrário. Ora incluída para amenizar no ensino a apresentação de visões epistemológicas "áridas" e para introduzir os alunos na "problemática dos diferentes autores que marcaram a disciplina", ora excluída em nome do "viés teorizante" e da tradição "pesadamente teórica" atribuída a certos cursos e instituições, o lugar da "história" é sempre subsidiário, complementar; ela é vista apenas como pano de fundo das teorias. Uma entrevistada, de fato, concede valor à "história" para o ensino na graduação mais do que na pós-graduação, sendo esta última o lugar por excelência da "teoria".

\section{História e teoria antropológicas na "linha do tempo"}

Apesar de certa contundência com que os professores entrevistados distinguem a "teoria" da "história", tal divisão não se sustenta na análise dos programas das disciplinas obrigatórias. Isto parece especialmente evidente a propósito das diferenças aventadas tão insistentemente entre as disciplinas de cunho histórico e as de cunho teórico. Independente do nome oficial das disciplinas, de seus objetivos explícitos e do local de ensino, ao menos dois fatos permitem constatar que tais diferenças inexistem: 1. A seleção dos conteúdos que, como se verá adiante, são substantivamente os mesmos, assim como sua organização, que segue a mesma sequência; 2 . As tendências para a inclusão e o predomínio de certos autores nos programas, que são sistematicamente as mesmas. Dito de outro modo, é possível considerar as disciplinas "históricas" e "teóricas" numa única classe porque seus conteúdos e sua organização são formalmente equivalentes, independendo da maneira como tais disciplinas são nomeadas, de seus objetivos explícitos e do local de ensino. Ao comparar os programas das disciplinas de cunho histórico e teórico, assim como os regimentos dos seis PPGAs, vê-se que elas se ajustam a um esquema geral, a partir de um objetivo comum que pode ser enunciado sinteticamente assim: introduzir os alunos no conhecimento da antropologia através do estudo de autores e tradições intelectuais nacionais, de obras e de problemas e teorias (os clássicos), considerando a história do campo e o contexto em que ele se desenvolveu. 
A análise neste nível, além de identificar os autores que, pela sua recorrência, configurariam um certo cânone (cf. Vega Sanabria 2005), sugere um fato tão ou mais revelador quanto este: a possibilidade de reunir em três categorias relacionadas disciplinas consideradas pelos professores entrevistados como de natureza e propósitos diferentes. ${ }^{5}$ Cada uma dessas categorias corresponderia a um "núcleo consensual" no que se refere ao cânone de autores e obras, em virtude dos propósitos das disciplinas nelas reunidas. Estas classes correspondem, no contexto da pesquisa, ao que denominei núcleos consensuais de primeiro, de segundo e de terceiro níveis, precisamente tendo em vista a natureza das disciplinas envolvidas em cada caso. Um núcleo consensual de quarto nível poderia ser ainda incluído, se consideradas as disciplinas optativas.

A organização piramidal destes quatro núcleos no Gráfico 1 denota sobretudo a antecedência temporal e uma relação instrumental no contexto do ensino. $\mathrm{O}$ fato de um núcleo consensual ocupar no gráfico uma posição inferior em relação a outro não informa necessariamente sobre o valor atribuído nos PPGAs ao conjunto das disciplinas que compõem tal núcleo, mas que, do ponto de vista "nativo", sem ele não seria possível existir o seguinte núcleo. Ademais, a pirâmide representa graficamente a classificação que distingue, nos PPGAs, disciplinas "básicas" (os dois ou três primeiros núcleos, dependendo do PPGA) e disciplinas "de ponta", isto é, as optativas. Estas últimas, como descritas pelos entrevistados, não estão propriamente tão preocupadas em enfatizar a tradição e em propiciar uma formação básica dos alunos, mas apontam para o estudo de "coisas novas, literatura recente".

A continuidade programática que se estabelece nos cursos entre as disciplinas do núcleo consensual de primeiro nível e as de segundo configura, de acordo com a descrição de um entrevistado, "uma linha clássica", "fundadora do campo disciplinar". Essa sequência e suas duas grandes divisões são descritas, assim, sinteticamente por outra entrevistada:

[...] TAI [Teoria Antropológica I] e TAII [Teoria Antropológica II] foram produtos de uma discussão, de uma negociação. A ideia era que a gente tinha que dar um panorama das antropologias, da antropologia desde seu início. Então, a gente concebeu, um pouco cronologicamente, alguma coisa que fosse até os anos 50 para TAI, e dos anos 50 para cá, no caso de TAII. Claro, isso depende de professor para professor, porque às vezes o professor de TAI vai até os anos 60, depende um pouco. Mas a ideia era dar um panorama da antropologia, sem necessariamente um viés histórico, embora haja um viés cronológico, porque TAI pega o início e TAII pega um período mais recente. 


\section{Gráfico 1 - Um modelo da configuração do cânone de autores e} obras em seis Programas de Pós-graduação em Antropologia no Brasil

Nivel Consensual de Quarto Nível

Disciplinas optativas

Nível Consensual de Terceiro Nível (Metodológico)

Seminário de Projeto USP

Seminário de Doutorado UFRGS

Seminário de História e Teoria UFPE

Métodos e Técnicas de Pesquisa Antropológica UFPE, UFRGS

Métodos e Técnicas de Pesquisa Antropológica I e II UFSC

Nível Consensual de Segundo Nível (Histórico-Teórico)

História e Teoria Antropológica II UFPE

Seminário Avançado em Teoria I e II UnB

Teoria Antropológica I e II UFSC

Teoria Antropológica II MN, UFRGS, UFSC

Teorias Antropológicas Modernas USP

Nivel Consensual de Primeiro Nível (Histórico-Teórico)

$\begin{aligned} \text { História da Antropologia } & \text { UFSC } \\ \text { História da Antropologia: Autores Clássicos I e II } & \text { UnB } \\ \text { História e Teoria Antropológica I } & \text { UFPE } \\ \text { Teoria Antropológica I } & \text { MN, UFRGS } \\ \text { Teorias Antropológicas Clássicas } & \text { USP }\end{aligned}$


Quando interrogados sobre a origem dessa classificação, alguns entrevistados respondiam de modo categórico: "essa divisão sempre existiu". Curiosamente, sua compreensão parecia não reconhecer "nenhuma grande lógica", "nenhuma razão teórica" nessas divisões, mas "simplesmente soluções em grande parte de bom senso, empíricas", ou uma "razão prática". Alguns entrevistados, aliás, mostraram-se inconformados em face do "viés cronológico" citado acima, afirmando que na organização das disciplinas "outras abordagens são possíveis". Porém, como revelariam as análises posteriores, a possibilidade de identificar o que poderia ser proposto como um cânone de autores no ensino dependeria justamente das divisões temporais que se estabelecem na sequência dos conteúdos nas disciplinas obrigatórias. Essas divisões temporais também estariam atreladas a outras formas de classificação, notadamente as que derivam do forte contraste que é feito no ensino entre noções como "clássico" e "contemporâneo", ou entre "história" e "teoria", tal como é representado na sequência no Gráfico 2.

\section{Gráfico 2 - Um esquema da organização dos conteúdos nas disciplinas obrigatórias de} cunho histórico e teórico em seis Programas de Pós-graduação em Antropologia no Brasil*

\begin{tabular}{|c|c|c|c|c|c|c|}
\hline \multicolumn{4}{|c|}{$\begin{array}{l}\text { Nível consensual de Primeiro nível } \\
\text { Clássico }\end{array}$} & \multicolumn{3}{|c|}{$\begin{array}{l}\text { Nível consensual de Segundo nível } \\
\text { Contemporâneo }\end{array}$} \\
\hline $\begin{array}{l}\text { Evolucionismo } \\
\text { (Vitoriano) }\end{array}$ & $\begin{array}{l}\text { Culturalismo } \\
\text { Norte-americano }\end{array}$ & Antropologia Social Britânica & $\begin{array}{l}\text { Escola Sociológica } \\
\text { Francesa }\end{array}$ & Estruturalismo & Hermenêutica & $\begin{array}{l}\text { Antropologia } \\
\text { Pós-moderna }\end{array}$ \\
\hline $\begin{array}{l}\text { Rivers } \\
\text { Morgan } \\
\text { Tylor Frazer }\end{array}$ & $\begin{array}{l}\text { Boas } \\
\text { M. Mead } \\
\text { Benedict }\end{array}$ & $\begin{array}{l}\text { Malinowski, Radcliffe-Brown } \\
\text { Evan-Pritchard, Fortes } \\
\text { Firth } \\
\text { Douglas } \\
\text { Gluckman }\end{array}$ & $\begin{array}{l}\text { Durkheim } \\
\text { Mauss } \\
\text { Lévi-Bruhl } \\
\text { Dumont }\end{array}$ & Lévi-Strauss & Geertz & $\begin{array}{l}\text { Marcus } \\
\text { Rabinow }\end{array}$ \\
\hline
\end{tabular}

\footnotetext{
* Embora aqui não se incluam as percentagens, os autores em cada quadro correspondem, nessa ordem, aos autores de cada "escola" mais citados nos programas de disciplinas, conforme o levantamento estatístico realizado.
} 
As disciplinas do núcleo consensual de segundo nível, via de regra, "começam com Lévi-Strauss e se abrem para os autores mais contemporâneos", abarcando aproximadamente o período entre o final da década de 1960 ou início da de 1970 até a atualidade. Em outros termos, compreendem a "fase pós-clássica" da antropologia, como é denominado esse período num programa de disciplina. A comparação entre as disciplinas destas duas classes permite a alguns entrevistados advertir sobre a possibilidade de introduzir maiores ou menores modificações, dependendo do tipo de disciplina a ser ministrada. O depoimento de um entrevistado é particularmente interessante neste sentido, uma vez que, após mais de 30 anos num PPGA, nunca ministrou a disciplina do primeiro núcleo, enquanto o fez muitas vezes a do segundo, precisamente porque esta disciplina estaria mais próxima de seus interesses temáticos. O entrevistado chama a atenção para um certo "conservadorismo" das disciplinas do núcleo de primeiro nível, em virtude das poucas possibilidades de modificação dos conteúdos e, conforme sua própria expressão, a relação "reificante" que tende a se estabelecer com os autores considerados "clássicos" nesse nível.

Eu acho que essa ideia de TAI também corre um certo risco de reificar determinado panteão de autores e os chamados clássicos. Eu acho que às vezes fica um pouco conservador. Eu não sou totalmente contra, mas acho que precisava botar um pouquinho de pimenta às vezes. Eu acho que a gente tem uma certa resistência a incorporar as novidades, o que até certo ponto é salutar, porque há muitas modas que passam e realmente não deixam muita coisa de bom. Mas eu acho que, de qualquer maneira, é muito importante na formação de nossos alunos que eles tenham também essa abertura para o que está acontecendo de mais recente, para as novas tendências do campo. TAI tem uma certa tendência conservadora. O que é bom e mau ao mesmo tempo.

O ensino das disciplinas do primeiro núcleo às vezes pode ser considerado "mais fácil" precisamente porque haveria uma "receita", uma vez que "a própria comunidade antropológica [já] sabe os autores pelos quais você vai passar". As disciplinas do segundo núcleo ofereceriam possibilidades de explorar uma pauta mais ampla, em razão das preferências dos professores responsáveis. Assim, amiúde, elas são orientadas tematicamente, podendo até incluir títulos (o que não acontece com as disciplinas do primeiro núcleo). No PPGA da UnB, por exemplo, os conteúdos do "Seminário Avançado em Teoria" (I e II) articularam-se no início dos anos 2000 em torno de temáticas gerais como "cultura e poder", "antropologias mundiais", "racionalismo, relativismo e conflito de interpretações" e "noções de corpo e pessoa", em contraste com 
os conteúdos mais genéricos da disciplina "História da Antropologia: Autores Clássicos" (I e II). Na UFSC, disciplinas como "Teoria Antropológica" (I e II) foram organizadas tomando como eixos temáticos o "binômio cultura/natureza" ou "cultura/sistema cultural" e "sociedade/sistema social" e as conexões entre conceitos como "cultura", "contato" e "poder-política", em contraste com a abordagem também mais "genérica" da disciplina "História da Antropologia".

Todavia, segundo alguns entrevistados, se a possibilidade de inovar é mínima nas disciplinas do primeiro núcleo consensual, nas do segundo ela "não é absoluta". E se antes da adoção das atuais grades curriculares a organização das disciplinas "ficava dependendo muito do professor", atualmente existe "um acordo geral" sobre a necessidade de um "mínimo modelo". Afinal, há uma "grade mínima", embora "às vezes haja alguns professores que escapam um pouquinho" da sequência estabelecida para uma disciplina do segundo núcleo - precisamente porque ela seria "um pouco mais flexível". Por isso, mesmo reconhecendo que "existe um elemento de subjetividade e de preferência pessoal" na montagem de uma disciplina do segundo núcleo, um entrevistado adverte: "certamente, no meu curso, não estou dando só aquilo de que gosto, mas aquilo que eu sinto obrigação realmente de comunicar aos alunos". Ele é enfático afirmando que é necessário "seguir, digamos assim, a voz corrente, quase o senso comum da disciplina". Uma entrevistada acrescenta ainda que existe, de fato, um "acordo implícito" acerca do que "deve ser" a sequência das disciplinas dos dois primeiros níveis e, a seu ver, "os colegas se conformam a esse acordo implícito".

Além das balizas estabelecidas pelas grades curriculares assim formalizadas e, segundo sugere essa entrevistada, pelos controles sociais que se exercem sobre elas, uma outra situação também parece contribuir no estabelecimento e na continuidade do modelo curricular como um todo. Tal situação concerne a um traço da configuração acadêmico-institucional dos PPGAs no Brasil e, decerto, também às condições financeiras que pautam seu desenvolvimento. Ela é descrita sinteticamente por um entrevistado nos seguintes termos:

Uma coisa que me chama a atenção nesses cursos introdutórios nossos é que eles pretendem dar um panorama geral da antropologia, mas, na verdade, nós só conseguimos realizar isso parcialmente, porque a antropologia que nós praticamos na nossa instituição não inclui todas as linhas da antropologia contemporânea. Esse é um lado da antropologia que nós não praticamos, ou seja, primeiro há uma tendência institucional, [pois] acho que nosso gosto pela diversidade também não é tão grande assim, é um pouco mais limitado. E, segundo, também há dificuldades financeiras. Não temos nem condições de ter tudo isso aqui. Antes já tivemos mais do que hoje... 
Duas ideias podem ser aventadas, enfim, a propósito desta descrição. Primeiro, a existência no ensino de um cânone operacional, sim, mas de alguma forma incompleto. Segundo, a antropologia que se ensina reproduziria, ao menos nos aspectos supracitados, a antropologia que se faz, mas também refletiria aquela que não se faz em cada instituição.

\section{A antropologia historicizada ou os índios de Fenimore Cooper}

As distinções entre clássico e contemporâneo e entre história, teoria e método até aqui expostas de nenhum modo postulam diferenças ontológicas entre as categorias nativas que estes termos expressam, isto é, os juízos de relação entre estes termos não se enunciam aqui como atributos dos objetos que eles representam (Lévi-Strauss 1998:108). Mas tendo em vista o forte contraste que em geral os entrevistados estabelecem entre eles, tais termos servem como balizas para descrever as atitudes subjetivas que parecem permear algumas de suas posturas em relação ao ensino. Parafraseando Lévi-Strauss, "clássico", "contemporâneo", "história", "teoria" e "método" não são, pois, nunca o clássico, o contemporâneo, a história, a teoria ou o método, mas o clássico para, o contemporâneo para, a história para, a teoria para, o método para... (1962:307).

Se, como foi sugerido antes, a diferença entre "história" e "teoria" antropológicas não parece se sustentar objetivamente no ensino, como entender as insistentes distinções que os professores entrevistados fazem entre elas? E se na formalização do ensino elas não se distinguem, será que nesse contexto a história da antropologia se torna (equivocadamente) teoria antropológica, como adverte Peirano (2004:103-104) a propósito do tratamento dado no Brasil ao trabalho de um historiador da antropologia como Stocking? $\mathrm{Ou}$, ao contrário e apesar dos esforços para ir além de uma "simples" abordagem "histórica", será que as tentativas para ensinar "teoria" antropológica ficariam apenas no patamar da "história" da antropologia? Eis aqui o que seria um paradoxo no tratamento nativo desta questão: ao mesmo tempo em que se supervalorizam as diferenças entre "história" e "teoria", na organização do ensino a "teoria" parece virar "história" ou a "história" virar "teoria". Na base desse paradoxo estariam, por um lado, a maneira de hierarquizar o conhecimento antropológico que valoriza a "teoria" em detrimento da "história". Por outro lado, o fato simultâneo de que o ensino seja orientado, segundo o modelo predominante, para a reconstrução de uma história disciplinar centrada na sucessão cronológica e geográfica de indivíduos (os autores "clássicos") e das chamadas "tradições antropológicas nacionais". 
Alguns programas, de fato, problematizam em suas ementas e introduções esse modelo, quando adotado na respectiva disciplina. Eles advertem explicitamente sobre sua "precariedade" e exortam para não "conferir excessiva importância a esse tipo de recorte" porque ele seria "meramente indicativo". O recorte deveria ser entendido "mais em função de necessidades didáticas do que de considerações de natureza mais substantivas"; o que em realidade se buscaria seria "uma reflexão sobre modelos analíticos" e não "um roteiro para uma história da antropologia". Esses programas também lamentam que a bibliografia selecionada "deixe de lado" autores, textos e "outras importantes tradições", e chamam a atenção para o fato de que "alguns recortes consagrados (como a divisão em 'três grandes tradições metropolitanas') [França, Grã Bretanha e Estados Unidos] parecem sofrer contestação quanto a seu poder de dar conta do(s) sentido(s) do conjunto da produção da disciplina".

O esquema geral por meio do qual são dispostos os conteúdos das disciplinas obrigatórias desdobra-se, em todo caso, numa seleção paradigmática que expressaria uma forma particular de historicizar o próprio campo antropológico. A maneira como opera essa forma de historicizar a antropologia no ensino pode ser entendida como um processo de sobrecodificação, isto é, uma operação cognitiva por meio da qual se esmagam oposições internas de cada "tradição" — pois o que se sobrecodifica são precisamente suas diferenças - e se gera uma espécie de plasticidade que permite ao grupo social situar-se em um plano de abstração onde distingue "nós" de "os outros" (Goldman \& Lima 1999:89-90). Pense-se aqui, por exemplo, na maneira como se apela no ensino para os autores "clássicos" e se entendem as relações entre antropólogos a partir da criação de "linhagens" intelectuais, invocando vínculos com certas "tradições nacionais" e com "pais fundadores", "ancestrais" comuns de uma linha de "descendência".

Peirano (1995:10-11) e Corrêa (1997:84), por exemplo, assinalam o duplo caráter de vínculo acadêmico e mítico deste tipo de filiações - Peirano usa a expressão "panteão teórico-cosmológico" de autores. Sendo que história disciplinar e vínculos entre gerações parecem desdobrar-se enquanto extensão social das ações desses pais fundadores, o caráter mítico atribuído às filiações também pode ser visto como se exprimisse uma concepção nativa da história ou, nos termos de Wilhelm Mühlmann, uma "teoria histórica" indígena (apud Schaden 1989). Mas ao mesmo tempo em que a compreensão mítica das relações expressa essa teoria nativa da história, a "história" como é apresentada no ensino contribui — num movimento inverso - para a produção da mitologia nativa precisamente porque permite a socialização dos jovens com a tradição dos "ancestrais" e a reprodução das ditas "linhagens" 
(antropológicas). Deste modo, a história mítica permite tanto explanar as origens do grupo quanto justificar os vínculos sociais, porque, como coloca Corrêa ao recuperar a história das "linhagens femininas" em antropologia: "a reivindicação dessas predecessoras independe, de certo modo, do que quer que elas tenham feito: sua reinscrição (agora qualificada) no corpo canônico da disciplina expressa muito mais a nossa necessidade contemporânea do que retrata as suas trajetórias profissionais [...]" (1997:92).

Essa teoria histórica talvez encontre no contexto local sua formulação discursiva mais elaborada na ideia de "história teórica" proposta por Peirano $(1995,1997,2004,2006 b)$. Para ela, o estudo dos autores (brasileiros e estrangeiros, clássicos e contemporâneos) surge como "condição indispensável para localizar o ponto de partida disciplinar como um todo e o contexto particular de fala", uma vez que "o novo se constrói sobre os ombros dos antecessores" (1995:11-12). Os clássicos tornar-se-iam, assim, "criações sociologicamente necessárias e teoricamente indispensáveis". Segue-se daí a necessidade de um "diálogo" permanente entre os problemas e os métodos atuais e aqueles propostos pelos "fundadores da disciplina". Expressas as reservas perante o estabelecimento de uma mera história ou de uma mera historiografia da antropologia, Peirano sugere que na abordagem do desenvolvimento da disciplina a "teoria antropológica é teoria-e-história da antropologia, da mesma forma que é teoria-e-etnografia" (1997:20).

Contudo, apesar dos alertas em relação à historiografia e de que, como dito acima, outras abordagens são possíveis no ensino, a explicitação de tais reservas contrasta fortemente com o predomínio de uma forma de história heroica nos programas das disciplinas obrigatórias. De fato, exprimir tais reservas não necessariamente conduz a que, inclusive nos programas de disciplinas nos quais isto é feito, sejam seguidas outras formas de historicizar a antropologia. Mesmo quando, como exposto num desses programas, se pretende analisar as "condições de produção do conhecimento", o "contexto objetivo e subjetivo do debate e dos indivíduos que estão se inserindo nesse debate; todo o capital social, cultural, que esses indivíduos trazem [...] e que acionam no momento de produção do conhecimento", o contexto parece surgir apenas como "pano de fundo", isto é, apenas para explicar as obras de indivíduos excepcionais (Braudel 1974).

Nessa forma de historização que origina a sequência dos conteúdos nas disciplinas obrigatórias observam-se também os traços de uma concepção linear do tempo e, logo, sua segmentação em unidades discretas sob a forma de "tradições antropológicas nacionais". A singularidade desse tempo objeto da vivência de seres humanos, distinto do tempo como objeto científico (Jaguaribe 2003; Oliveira 2003), precisamente por sua natureza 
subjetiva, torna-se evidente se comparada com noções de tempo e de história em outros campos disciplinares. Por exemplo, um entrevistado formado primeiro numa área distinta à das ciências sociais, recorda seu estranhamento inicial, quando era doutorando em antropologia, diante da antiguidade dos textos usados no ensino. O entrevistado relembra que o livro mais antigo, considerado "clássico" na área da qual ele provinha, tinha apenas 12 anos de publicado. Diante disso, ele acrescenta:

Imagina sair de uma disciplina como essa e cair numa outra, sendo os textos de início do século sobre troca de braceletes e colares. [Eu me perguntava:] esse texto tem quantos anos? Tem 60 ! Como é que vou ler um texto de 60 anos, isso não tem cabimento! Um texto sobre totemismo com 80 !... A primeira descoberta que eu fiz é que a antropologia tinha uma outra velocidade. Você não julgava um texto pela antiguidade. O Ensaio sobre o dom, o Ensaio sobre a dádiva [de Marcel Mauss], era um desses textos. Também tinha A ética protestante [de Max Weber]. E bom, comecei então a apreender não só o conteúdo de uma outra disciplina, mas apreender a cultura de uma nova disciplina.

O ritmo acelerado da mudança na área de formação inicial desse entrevistado contrasta com a forma de historicizar a antropologia no ensino, mas também com uma prática habitual na montagem das disciplinas obrigatórias nos cursos. Essa prática consiste em retomar os programas dos professores que ministraram antes certa disciplina e introduzir algumas modificações quando não retomar com maior ou menor fidelidade os programas padronizados ou listas de bibliografia selecionada previamente em alguns cursos. Esta prática aparece plenamente justificada por uma entrevistada ao afirmar: "a gente sempre presta atenção às cadeiras dadas no passado. Porque consideramos que já tem uma tradição de professores ultracompetentes que deram essas disciplinas e a gente lucra com a experiência de outras pessoas" (grifos meus). Ela acrescenta ainda: "nunca ouvi falar de um professor que inventa o programa do nada. É como qualquer pesquisador: você tem a obrigação de pegar o que teus predecessores fizeram com êxito e tentar pensar a partir disto. E aí você vai aumentando ou diminuindo um pouco". Nesta esteira, outra entrevistada afirma que, em geral, um professor desenvolve um programa, "grande parte do qual ele fez como aluno".

Assim, reafirmam-se a privilegiada posição de que gozam os "clássicos" e a maneira como a historização do próprio campo parece operar no ensino. E se, como foi sugerido, a forma de historicizar a antropologia e algumas das práticas na montagem das disciplinas reforçam a ideia de um tempo linear e discreto na apresentação de uma tradição estabelecida, poder-se-ia 
dizer, retomando uma caracterização proposta por Elman Service e citada por Sahlins (1990:64), que na produção da história heroica apresentada no ensino de antropologia, antropólogos procedem como os índios de Fenimore Cooper: "enquanto anda em fila indiana ao longo da trilha, cada homem tem o cuidado de pisar nas pegadas de quem está à sua frente, de modo a deixar a impressão de que ali havia apenas um único índio gigantesco".

\section{Cânone e diferença no ensino de antropologia ${ }^{6}$}

Neste contexto pode se entender que, expostos a similares circunstâncias históricas, similares condições institucionais e similares processos de objetivação dos conteúdos do ensino, os cursos de antropologia no Brasil se caracterizam por uma considerável homogeneidade, ao menos no que diz respeito à sua formalização nas grades curriculares e nos recortes temáticos e bibliográficos das disciplinas obrigatórias. Esta afirmação somar-se-ia, aliás, às já feitas neste mesmo sentido por Schwarcz (2006) e Debert (2004). Sugerir que os cursos de antropologia no Brasil sejam bastante homogêneos entre si resulta tanto mais plausível quanto o fato de que em outros países a heterogeneidade da estrutura curricular e a dispersão de conteúdos e de orientações teóricas são apontadas como sérias dificuldades da formação (cf. Degregori et al. 2001; Srivastava 2000; Deshpande et al. 2000).

Esta constatação é interessante por duas razões. Primeiro, porque verificar a homogeneidade contrastaria com a ênfase dada pelos professores entrevistados às diferenças entre os PPGAs. Segundo, porque talvez, reconhecendo-a, tal homogeneidade serviria como pano de fundo no qual eventuais diferenças ficariam mais evidentes. Em outras palavras, o fato de que do ponto de vista formal as diferenças resultem pequenas ou possam ser "apagadas" - para usar a expressão de alguns entrevistados — não nega a possibilidade de considerar ainda valores diferenciais entre os cursos e da formação em antropologia. Tratando-se de possíveis diferenças, duas vias mereceriam ser exploradas empiricamente: o ensino a partir das disciplinas optativas e a formação através dos processos de orientação. Isto porque, em contraste com as disciplinas obrigatórias que vinculariam os alunos ao cânone da tradição antropológica, as disciplinas optativas e a orientação os aproximariam do capital material e social dos grupos de pesquisa e do capital vinculado às trajetórias dos orientadores. Perante a marca geral e homogeneizante da formação obrigatória, o caráter particularizante das disciplinas optativas e da orientação garantiria, em termos de experiência subjetiva, um fator de diferenciação social mais determinante. As marcas 
de distinção social no interior de e entre os PPGAs derivariam então da inserção do aluno nos grupos de pesquisa e do contato privilegiado com seu orientador, e não simplesmente da passagem pela instituição ou apenas pela exposição aos conteúdos do ensino.

Em outras palavras, a especialização no âmbito das disciplinas optativas e da orientação encontraria seu correlato na singularidade das relações sociais através da inserção nos grupos de pesquisa e da troca com um orientador. Seriam precisamente a especialização da formação e a singularidade das relações que, em última análise, gerariam o valor diferencial da experiência formativa. A marca institucional em abstrato cederia terreno, assim, ao fato concreto de ter sido orientando, ou de ter sido aluno de tal ou qual professor, ou de ter participado da experiência de pesquisa no interior de um grupo específico. É neste contexto que a ideia exposta pelos professores entrevistados acerca de que ninguém "se tornaria" antropólogo no curso em si, nem através da passagem pelas disciplinas, mas pela orientação, parece adquirir pleno sentido.

A vinculação às linhas de pesquisa e a identificação com os interesses intelectuais e os estilos dos professores emergiriam, aliás, como os elementos idiossincráticos por excelência. Isto porque, como também sugerem os entrevistados, é aqui que "os motivos pessoais se impõem, mais do que nas aulas", e porque "nesse processo de se tornar antropólogo, a gente investe mesmo é na orientação". Considerar esta dimensão especializada e personalizada da formação pode ser interessante à medida que situa a questão de eventuais signos de distinção para além da simples invocação de uma tradição institucional ou intelectual. Ela sugere então a pertinência de explorar outros aspectos do funcionamento dos programas de pós-graduação em novas pesquisas empíricas sobre o ensino, tais como os modos de organização dos núcleos e das linhas de pesquisa, a gestão de recursos e o desenvolvimento de trajetórias individuais e grupais em antropologia.

Recebido em 17 de setembro de 2014

Aprovado em 20 de abril de 2015

Guillermo Vega Sanabria é professor adjunto do Departamento de Ciências Sociais da Universidade Federal de Viçosa. E-mail: < vegasanabria@gmail.com>. 


\section{Notas}

* Agradeço os comentários generosos e estimulantes de dois pareceristas anônimos e dos professores Mariza Peirano e Luiz Fernando Dias Duarte sobre uma versão preliminar deste texto. Também agradeço a Maria Cecília Diaz a revisão das referências bibliográficas.

${ }^{1}$ Retomo aqui dados revisados de minha dissertação de mestrado (Vega Sanabria 2005), realizada sob a orientação da professora Miriam Hartung. Os dados sobre grades e disciplinas correspondem aos PPGAs (mestrado e doutorado) da Universidade de Brasília (UnB), da Universidade de São Paulo (USP) e das Universidades Federais de Pernambuco (UFPE), Rio de Janeiro (UFRJ/Museu Nacional), Rio Grande do Sul (UFRGS) e Santa Catarina (UFSC). As citações de entrevistas provêm, especificamente, do levantamento de informações in situ realizado em 2004 nos programas do Museu Nacional, UFPE, UFRGS e USP. Além de dois coordenadores e três secretárias desses PPGAs, foram entrevistados 25 professores que tinham lecionado disciplinas obrigatórias nos anos de 2001, 2002 e 2003, sendo este o principal critério para entrevistá-los. O diálogo com os professores permitiu explorar suas trajetórias pessoais - focando em sua experiência prévia como aprendizes de antropologia - a história da configuração das grades curriculares em cada PPGA e o processo de montagem das disciplinas obrigatórias por eles ministradas. A abrangência do trabalho de campo dependeu fundamentalmente da disponibilidade dos participantes e dos recursos e tempo disponível para uma pesquisa de mestrado. A amostra buscou garantir, contudo, um certo equilíbrio e representatividade, de acordo com critérios de antiguidade, distribuição regional e reconhecimento institucional dos PPGAs. Assim, ela incluiu três dos primeiros PPGAs (MN, UnB e USP) e três dos mais novos à época (UFPE, UFRGS e UFSC). A participação em termos regionais também buscou ser representativa da distribuição existente à época no país, sendo que havia um curso do Nordeste (UFPE, até 2005 o único da região com formação exclusiva em antropologia); dois cursos do Sudeste (MN e USP), um do Centro-Oeste (UnB, até então também o único da região com formação exclusiva em antropologia) e dois da região Sul (UFSC e UFRGS). Transcorrida uma década da pesquisa, o número de PPGAs no Brasil mais do que duplicou, chegando a mais de vinte. Porém, uma comparação rápida da estrutura das grades curriculares desses PPGAs e de outros recém-criados, assim como de alguns programas de disciplinas obrigatórias, sugere, muito interessantemente, que o modelo geral do ensino de antropologia se mantém o mesmo, pelo menos à luz da análise aqui proposta (por exemplo, em termos de "tradições antropológicas" nacionais).

${ }^{2}$ Uma análise mais densa - não desenvolvida aqui - poderia considerar os arranjos das grades curriculares e das disciplinas em face das condições institucionais em que conhecimentos antropológicos são selecionados e transmitidos no país à luz, por exemplo, do momento de criação dos PPGAs e as circunstâncias específicas que a fizeram possível, das dinâmicas organizacionais e das histórias locais e regionais dos antropólogos no Brasil, das formas e critérios de seleção dos professores e sua 
maior ou menor rotatividade entre disciplinas (a respeito desta última questão, ver a seção "Trabalho" em Vega Sanabria 2005).

${ }^{3}$ Treze dos 25 professores entrevistados doutoraram-se no estrangeiro: cinco na França, quatro na Grã-Bretanha, três nos Estados Unidos e um na Alemanha. Os 12 restantes formaram-se no Brasil: sete na USP e cinco no MN. Considerando todos os professores dos seis PPGAs da pesquisa, a relação estrangeiro-Brasil se inverte, mas os locais de referência continuam a ser os mesmos em ambos os casos. Segundo a informação dos sites desses programas em 2005, 62\% dos 101 professores permanentes tinham obtido seus doutorados no Brasil: $32 \%$ na USP, 18\% no MN, 7\% na UnB e os $5 \%$ restantes em outros locais. Dos 38\% de professores doutorados no estrangeiro, 14\% tinham-no feito nos Estados Unidos, 14\% na França, 9\% na Grã-Bretanha e 1\% na Alemanha (cf. dados similares até 2001 em Fry 2004:231 e Oliven 2004:217). Em 2014, de 116 professores permanentes nos mesmos seis programas de pós-graduação, 70\% tinham se doutorado no Brasil: 26\% no MN, 23\% na USP, $8 \%$ na UnB, $4 \%$ na Unicamp, 3\% na UFRGS, 3\% na UFSC e mais 3\% em outros locais. Os 30\% restantes doutoraram-se no estrangeiro: 11\% nos Estados Unidos, 10\% na França, 8\% na Grã-Bretanha e 1\% em outros países.

${ }^{4}$ Um trabalho de campo de mais fôlego, por exemplo, com entrevistas sucessivas, teria permitido que os professores entrevistados reagissem a esta constatação, dando-lhes a oportunidade de reelaborar seu raciocínio e, quiçá, que algumas das questões neste sentido pudessem ter sido respondidas de outro modo. Isto porque, como já advertira Seeger (1980), quanto maior é a socialização do antropólogo na "aldeia" em que pesquisa, mais interessantes serão as questões que pode levantar e mais interessantes ainda serão as respostas de seus anfitriões e interlocutores.

${ }^{5} \mathrm{O}$ levantamento estatístico - básico, mas abrangente - apresentado em Vega Sanabria (2005) oferece duas listas de autores e tipos de textos que, por sua recorrência nos programas das disciplinas obrigatórias do período 2001-2003, sugeririam um certo "cânone" dos autores "clássicos" no ensino, inclusive em termos de "escolas antropológicas" nacionais. Como essa lista deve ser considerada um exercício inicial, novas análises, com um recorte temporal mais amplo, seriam úteis para identificar eventuais constantes ou alterações nesse "cânone".

${ }^{6}$ Uma versão deste texto foi publicada em 2009 na seção Coluna Virtual do site http://www.antropologia.com.br. 


\section{Referências bibliográficas}

BOMENY, Helena \& BIRMAN, Patricia (orgs.). 1991. "Introdução: as ciências sociais no Brasil". In: Helena Bomeny; Patrícia Birman \& Antônio Luiz Paixão (orgs.), As assim chamadas ciências sociais: formação do cientista social no Brasil. Rio de Janeiro: UERJ/ Relume Dumará. pp. 9-17;

BOURDIEU, Pierre. 2003. "Sistemas de ensino e sistemas de pensamento". In: S. Miceli (org.), A economia das trocas simbólicas. 5a . ed. São Paulo: Perspectiva. pp. 203-229.

BRANDÃO, Maria do Carmo (org.). 1997. Anthropológicas. Pós-graduação em antropologia da UFPE. 20 anos de pós-graduação em antropologia: memória, tradição \& perspectivas. Série Especial Comemorativa, Ano II. Mimeo.

BRAUDEL, Fernand. 1974. La historia y las ciencias sociales. $3^{\mathrm{a}}$. ed. Madrid: Alianza.

CARDOSO DE OLIVEIRA, Roberto. 1997. Sobre o pensamento antropológico. $2^{\mathrm{a}}$. ed. Rio de Janeiro: Tempo Brasileiro.

CORREA, Mariza. 1995. "A antropologia no Brasil (1960-1980)". In: S. Miceli (org.), História das ciências sociais no Brasil. Vol. 2. São Paulo: Sumaré \& Fapesp. pp. 25-106.

. 1997. "O espartilho de minha avó: linhagens femininas na antropologia". Horizontes Antropológicos, 3(7):70-96. . 2006. "Damas \& cavalheiros de fina estampa, dragões \& dinossauros, heróis \& vilões". In: M. Grossi et al. (orgs.), Ensino de antropologia no Brasil: formação, práticas disciplinares e além-fronteiras. Blumenau: Nova Letra. pp. 105-110. DEBERT, Guita Grin. 2004. "Formação e ensino". In: W. Trajano \& G. L. Ribeiro (orgs.), O campo da antropologia no Brasil. Rio de Janeiro: Contra Capa/ ABA. pp. 143-161.
DEGREGORI, Carlos I.; ÁVILA, Javier \& SANDOVAL, Pablo. 2001. "Enseñanza de antropologia en el Perú". Serie Investigaciones Breves, 15. Lima: CIES/IEP. Disponível em: http://www.consorcio. org/CIES/html/pdfs/ib15.pdf. Acesso em: 24/10/04.

DESHPANDE, Satish; SUNDAR, Nandini \& UBEROI, Patrícia. 2000. "The problem. Situating sociology: a symposium on knowledge, institutions and practices in a discipline". Seminar Issue, 495. Disponível em: http://www.india-seminar.com/2000/495.htm. Acesso em: 07/06/04.

DUARTE, Luiz Fernando Dias. 2006. "Formação e ensino na antropologia social: os dilemas da universalização romântica". In: M. Grossi et al. (orgs.), Ensino de antropologia no Brasil: formação, práticas disciplinares e além-fronteiras. Blumenau: Nova Letra. pp. 10-17.

EVANS-PRITCHARD, Edward Evan. 1964. Social anthropology and other essays. Six Lectures on Third Programme of the BBC, Winter of 1950. New York: The Free Press. - 1978 [1940]. Os Nuer. uma descrição do modo de subsistência e das instituições políticas de um povo nilota. São Paulo: Perspectiva.

FONSECA, Claudia. 2006a. "Totens e xamãs na pós-graduação". In: M. Grossi et al. (orgs.), Ensino de antropologia no Brasil: formação, práticas disciplinares e além-fronteiras. Blumenau: Nova Letra. pp. 147-163.

- 2006b. "O exercício da antropologia: enfrentando os desafios da atualidade". In: M. Grossi et al. (orgs.), Ensino de antropologia no Brasil: formação, práticas disciplinares e além-fronteiras. Blumenau: Nova Letra. pp. 209-229. 
FORTINI, Franco. 1989. "Clássico". In: Enciclopédia Einaudi. vol. 17. Lisboa: Imprensa Nacional/ Casa da Moeda. pp. 295-305.

FRY, Peter. 2004. "Internacionalização da disciplina". In: W. Trajano Filho \& G. L. Ribeiro (orgs.), O campo da antropologia no Brasil. Rio de Janeiro: Contra Capa/ABA. pp. 227-248.

. 2006. "Formação ou educação: os dilemas dos antropólogos perante a grade curricular". In: M. Grossi etal. (orgs.), Ensino de antropologia no Brasil: formação, práticas disciplinares e além-fronteiras. Blumenau: Nova Letra. pp. 59-75.

GODOI, Emília Pietrafiesa de \& ECKERT, Cornélia (orgs.). 2006. Homenagens: Associação Brasileira de Antropologia: 50 anos. Blumenau: Nova Letra. GOLDMAN, Marcio \& LIMA, Tânia Stolze. 1999. "Como se faz um grande divisor?" In: M. Goldman, Alguma antropologia. Rio de Janeiro: Relume Dumará/ Núcleo de Antropologia Política. pp. 83-92.

GROSSI, Miriam; TASSINARI, Antonella \& RIAL, Carmen (orgs.), 2006. Ensino de antropologia no Brasil: formação, práticas disciplinares e além-fronteiras. Blumenau: Nova Letra.

HUTZLER, Celina Ribeiro. 1997. "A antropologia em Pernambuco: tradição e atualização". Anthropológicas. Pós-graduação em antropologia da UFPE. 20 anos de pós-graduação em Antropologia: memória, tradição \& perspectivas. Série Especial Comemorativa, Ano II. pp. 41-55. Mimeo.

JAGUARIBE, Helio. 2003. "Tempo e história". In: M. Doctors (org.), Tempo dos tempos. Rio de Janeiro: Zahar. pp. 156-165.

LARAIA, Roque de Barros. 1991. "Ensino das ciências sociais, hoje". In: H. Bomeny \& P. Birman (orgs.), As assim chamadas ciências sociais: formação do cientista social no Brasil. Rio de Janeiro: UERJ/ Relume Dumará. pp. 57-63.
2008. "Trajetórias convergentes: Cardoso de Oliveira e Maybury-Lewis". Mana. Estudos de Antropologia Social, 14(2):547-554.

LATOUR, Bruno \& WOOLGAR, Steve. 1997. A vida de laboratório: a produção dos fatos científicos. Rio de Janeiro: Relume Dumará.

LÉVI-STRAUSS, Claude. 1962. La pensée sauvage. Paris: Plon.

. 1998. "Lévi-Strauss nos 90: voltas ao passado". Mana. Estudos de Antropologia Social, 4 (2):107-117.

MAUSS, Marcel. 1969. "Fragment d'un plan de sociologie générale descriptive". In: Ouvres. vol. III. Paris: Minuit. pp. 314-346. MOTTA, Antonio \& BRANDÃO, Maria do Carmo. 2004. "O campo da antropologia e suas margens: a pesquisa e sua disseminação em diferentes instituições de ensino superior no Nordeste". In: W. Trajano \& G. L. Ribeiro (orgs.), O campo da antropologia no Brasil. Rio de Janeiro: Contra Capa/ ABA. pp. 163-186.

MOTTA, Roberto. 1997. "Um mestrado de antropologia em Pernambuco: reminiscências e perspectivas". Anthropológicas. Pós-graduação em antropologia da UFPE. 20 anos de pós-graduação em Antropologia: memória, tradição \& perspectivas. Série Especial Comemorativa, Ano II. pp. 15-39. Mimeo.

OLIVEIRA, Luiz Alberto. 2003. "Imagens do tempo". In: M. Doctors (org.), Tempo dos tempos. Rio de Janeiro: Zahar. pp. 33-68.

OLIVEN, Ruben G. 2004 "A reprodução da antropologia no Brasil". In: W. Trajano Filho \& G. L. Ribeiro (orgs.), 2004. O campo da antropologia no Brasil. Rio de Janeiro: Contra Capa/ABA. pp. 213-226. PEIRANO, Mariza. 1991. "Por um pluralismo renovado". In: H. Bomeny; P. Birman \& Antônio Luiz Paixão (orgs.), As assim chamadas ciências sociais: formação do cientista social no Brasil. Rio de Janeiro: UERJ/ Relume-Dumará. pp. 43-51. 
1995. A favor da etnografia. Rio de Janeiro: Relume-Dumará.

· 1997. "Onde está a antropologia?". Mana. Estudos de Antropologia Social, 3(2):67-102.

1999. "Antropologia no Brasil (alteridade contextualizada)". In: S. Miceli (org.), O que ler na ciência social brasileira (1970-1995). Antropologia vol. II. São Paulo: Sumaré. pp. 225-266. . 2004. "'In this context': as várias histórias da antropologia". In: F. A. Peixoto; H. Pontes \& L. M. Schwarcz (orgs.), Antropologias, histórias, experiências. Belo Horizonte: UFMG. pp. 99-121. - 2006a. A teoria vivida e outros ensaios de antropologia. Rio de Janeiro: Zahar.

. 2006b. "Um ponto de vista sobre o ensino da antropologia". In: M. Grossi et al. (orgs.), Ensino de antropologia no Brasil: formação, práticas disciplinares e além-fronteiras. Blumenau: Nova Letra. pp. 77-103.

RIBEIRO, Gustavo Lins \& LIMA, Antonio Carlos de Souza. 2004. "O campo da antropologia no Brasil". In: W. Trajano \& G. Lins Ribeiro (orgs.), O campo da antropologia no Brasil. Rio de Janeiro: Contra Capa/ABA. pp.7-12.

RIBEIRO, René \& HUTZLER, Celina R. 1991. "A institucionalização da antropologia cultural na Universidade Federal de Pernambuco". In: H. Bomeny; P. Birman \& Antônio Luiz Paixão (orgs.), As assim chamadas ciências sociais: formação do cientista social no Brasil. Rio de Janeiro: UERJ/ Relume-Dumará. pp. 65-77.

RUBIM, Christina de Rezende. 1996. Antropólogos brasileiros e a antropologia no Brasil: a era da pós-graduação. Tese de Doutorado, PPGCS/Unicamp. SAHLINS, Marshall. 1990. Ilhas de história. Rio de Janeiro: Zahar.

SANCHIS, Pierre. 2006. "Uma leitura dos textos da Mesa Redonda sobre o ensino das ciências sociais em questão: a antropologia". In: M. Grossi et al. (orgs.). Ensino de antropologia no Brasil: formação, práticas disciplinares e além-fronteiras. Blumenau: Nova Letra. pp. 111-125.

SANTOS, Silvio Coelho dos. 1997. "Notas sobre a construção da antropologia social no Brasil". Horizontes Antropológicos, 3(7):62-69.

SCHADEN, Egon. 1989. A mitologia heroica de tribos indígenas do Brasil. $3^{\mathrm{a}}$. ed. São Paulo: Edusp.

SCHWARCZ, Lilia. 2006. "Ensino de pós-graduação em antropologia: algumas primeiras notas comparativas". In: M. Grossi et al. (orgs.), Ensino de antropologia no Brasil: formação, práticas disciplinares e além-fronteiras. Blumenau: Nova Letra. pp. 231-248. SEEGER, Anthony. 1980. "Pesquisa de campo: uma criança no mundo". In: Os índios e nós. Rio de Janeiro: Campus. pp. 25-40.

SRIVASTAVA, Vynay K. 2000. "Teaching anthropology". In: S. Deshpande, N. Sundar \& P. Uberoi (orgs.), Situating sociology: a symposium on knowledge, institutions and practices in a discipline. Seminar Issue 495. Disponível em: http://www.india-seminar.com/2000/495. $\mathrm{htm}$. Acesso em: 07/06/04.

TAVARES, Fátima; GUEDES, Simoni Lahud \& CAROSO, Carlos. 2010. Experiências de ensino e prática em antropologia no Brasil. Brasília, DF: Ícone.

TRAJANO FILHO, Wilson. 2006. "Quebrando (ainda que lentamente) a inércia: uma proposta de criação do curso de graduação em antropologia". In: M. Grossi et al. (orgs.), Ensino de antropologia no Brasil: formação, práticas disciplinares e além-fronteiras. Blumenau: Nova Letra. pp. 281-298. - \& RIBEIRO, Gustavo Lins. 2004. O campo da antropologia no Brasil. Rio de Janeiro: Contra Capa/ABA. 
VEGASANABRIA, Guillermo. 2005. O ensino de antropologia no Brasil: um estudo das formas institucionalizadas de transmissão da cultura. Dissertação de Mestrado, PPGAS/UFSC.

VIVEIROS DE CASTRO, Eduardo. 1995. "Sobre a antropologia hoje: te(i)mas para a discussão". In: M. Peirano (org.), O ensino da antropologia no Brasil. Temas para uma discussão. Rio de Janeiro: ABA. pp. 5-9.

WOORTMANN, Klass. 2006. "Breve contribuição pessoal à discussão sobre a formação de antropólogos". In: M. Grossi et al. (orgs.), Ensino de antropologia no Brasil: formação, práticas disciplinares e além-fronteiras. Blumenau: Nova Letra. pp. 165-190. 
Resumo

Este artigo trata da relação entre o desenho das grades curriculares em programas de pós-graduação em antropologia (PPGA), a seleção de conteúdos de disciplinas obrigatórias e a compreensão que, nestes programas, professores têm sobre as obras e os autores tidos como clássicos e seu lugar no ensino. Parte da ideia de que as características das grades e certas tendências a respeito de autores, textos e temas propostos nas disciplinas obrigatórias exprimem uma hierarquização do conhecimento antropológico destinado ao ensino neste nível. Essa hierarquização remete a um cânone para a formação dos novos antropólogos no Brasil, mas também a traços idiossincráticos das relações sociais nos cursos de antropologia. Com base na análise qualitativa de grades e programas de disciplinas em seis PPGAs no Brasil e a revisão de arquivos e entrevistas com professores e coordenadores dos cursos em quatro dos seis PPGAs iniciais, temas como relações interinstitucionais e intergeracionais, divisão do trabalho e reprodução social surgem no âmago da reflexão sobre o ensino, à luz de noções como "clássicos" e "história".

Palavras-chave Ensino de antropologia no Brasil, História da antropologia no Brasil, Educação superior, Currículo universitário.

\section{Abstract}

This article analyses the relationships between curricula, the content of compulsory disciplines, and lecturers' understanding of the role of "classical" authors and works in six Brazilian postgraduate programmes in Anthropology. The article starts from the premise that the selection of authors, works and subjects in anthropology courses conveys a hierarchy of anthropological knowledge for teaching purposes. This hierarchy defines a canon for training new anthropologists in Brazil, but it also reflects idiosyncratic features of social relation in Anthropology postgraduate programmes. Based on a qualitative analysis of curricula and syllabuses in six programmes, as well as archival research and interviews with lecturers in four of the six programmes under analysis, topics such as inter-institutional and intergenerational relationships, division of labour, and social reproduction emerge as main questions in the light of notions as "classic" and "history".

Key words Teaching Anthropology in Brazil, History of Anthropology in Brazil, Higher Education, University curriculum. 